\title{
- STUDIES ON THE EFFECTS OF HUMAN GROWTH HORMONE IN PREMATURE INFANTS *
}

\author{
By JACQUES R. DUCHARME† ANd MELVIN M. GRUMBACH \\ (From the Department of Pediatrics, College of Physicians and Surgeons, Columbia University \\ and The Babies Hospital, New York, N. Y.)
}

(Submitted for publication June 20, 1960 ; accepted September 30, 1960)

The role of pituitary growth hormone during fetal and neonatal life remains uncertain even though it has been demonstrated repeatedly that hypophysectomy of the juvenile animal severely retards or arrests growth. The claim has been made that administration of growth hormone to normal pregnant rats stimulates growth of the fetus (2-5), but the evidence presented is inconclusive. In man, the macrosomia observed in infants born to prediabetic or diabetic mothers has been attributed by some to an excess of maternal circulating growth hormone $(4,6-9)$, thus implying transplacental passage of this growth-promoting substance and response of the fetal organism to exogenous hormone. Conversely, the normal birth weight of infants born to women with active acromegaly (10-12) and the relatively unimpaired growth of apituitary fetuses do not seem to support this hypothesis (13-18).

The biological effectiveness in man of primate growth hormone preparations has been clearly

* This work was supported by a grant from the $\mathrm{Na}$ tional Institute of Arthritis and Metabolic Diseases, National Institutes of Health, Bethesda, Md. Part of this study was reported in the discussion at the 1958 Laurentian Hormone Conference (1).

$\dagger$ Fellow in Pediatric Endocrinology. Present address : L'Hôpital Sainte-Justine, Montreal, Canada. established $(1,19)$, as has the lack of effectiveness of bovine, ovine or porcine growth hormone, providing an example of species specificity for a protein hormone (20). Accordingly, conclusions drawn from isolated reports of the effects of nonprimate growth hormone in infants may be questioned. The effects in the immature infant of the administration of a purified preparation of human growth hormone have been assessed in an attempt to elucidate the relationship of pituitary growth hormone to fetal and neonatal body growth.

\section{MATERIALS AND METHODS}

Five healthy premature infants weighing between 1,500 and $1,600 \mathrm{~g}$ at approximately 2 weeks of age and growing at a relatively steady rate were selected at random. The infants were fed a formula consisting of $12 \mathrm{~g}$ of Alacta ${ }^{1}$ and $7 \mathrm{~g}$ of glucose per $100 \mathrm{ml}$ water, which provided 0.77 calorie per ml. Feedings were administered every 3 hours through a polyethylene nasogastric tube until such time as the entire formula was taken adequately by nipple. Some infants at the end of the period of investigation were fed an evaporated milk formula consisting of 1 part of evaporated milk, 2 parts of water and 5 per cent cane sugar, which contained 0.66 calorie per $\mathrm{ml}$. The caloric intake was kept constant at 120 cal-

1 Alacta (Mead Johnson \& Co.), a powdered milk preparation, contains 4.3 calories per $\mathrm{g}, 33.0$ per cent protein, 12.0 per cent fat and 46.5 per cent carbohydrate.

TABLE I

Comparison of the treated infants and the dose schedule of hormone administration

\begin{tabular}{|c|c|c|c|c|c|c|c|c|c|c|c|c|c|c|c|}
\hline \multirow[b]{2}{*}{ Subject } & \multirow[b]{2}{*}{ Sex } & \multirow[b]{2}{*}{ Race } & \multirow{2}{*}{$\underset{\text { wt }}{\text { Birth }}$} & \multicolumn{2}{|c|}{ On day $0^{*}$} & \multicolumn{9}{|c|}{ Growth hormone in mg on Day } & \multirow[b]{2}{*}{ Total } \\
\hline & & & & Age & $\mathrm{wt}_{\mathrm{t}}$ & 0 & 1 & 2 & 3 & 4 & 5 & 6 & 7 & 8 & \\
\hline $\begin{array}{l}\text { Fel. } \\
\text { McM. } \\
\text { Hea. } \\
\text { Pig. } \\
\text { Mor. B }\end{array}$ & $\begin{array}{l}M \\
F \\
F \\
F \\
M\end{array}$ & $\begin{array}{l}\text { W } \\
W \\
W \\
W \\
W\end{array}$ & $\begin{array}{c}g \\
1,389 \\
1,380 \\
1,420 \\
1,400 \\
1,474\end{array}$ & $\begin{array}{c}\text { days } \\
40 \\
32 \\
31 \\
29 \\
22\end{array}$ & $\begin{array}{c}g \\
1,980 \\
1,910 \\
1,950 \\
1,760 \\
1,910\end{array}$ & $\begin{array}{r}1 \\
1 \\
2 \\
5 \\
10\end{array}$ & $\begin{array}{r}2 \\
5 \\
10\end{array}$ & $\begin{array}{r}1 \\
2 \\
5 \\
10\end{array}$ & 2 & $\begin{array}{l}1 \\
2\end{array}$ & & 1 & & 1 & $\begin{array}{r}m g \\
1 \\
5 \\
10 \\
15 \\
30\end{array}$ \\
\hline Bar. & $\mathrm{F}$ & W & 1,417 & 38 & 2,080 & $\underset{\text { Gro }}{\mathrm{AC}}$ & 1 & a & $x$ & & & & & & 40 \\
\hline
\end{tabular}

* Day 0 corresponds to the first day of growth hormone administration, except for Bar. for whom it is the first day of ACTH administration. Growth hormone was injected into Bar. on Days 10 to 13 inclusive. 
TABLE II

Comparison of infants in the control group

\begin{tabular}{lccccc}
\hline & & & & \multicolumn{2}{c}{ On day $0^{*}$} \\
\cline { 5 - 6 } Subject & Sex & Race & $\begin{array}{c}\text { Birth } \\
\text { wt }\end{array}$ & Age & Wt \\
\hline Mor. A & M & W & 1,620 & 22 & 1,960 \\
Bra. & F & W & 1,474 & 19 & 1,950 \\
Cam. & M & W & 1,701 & 20 & 1,820 \\
Stu. & M & W & 1,559 & 23 & 1,920 \\
Kno. & M & W & 1,588 & 23 & 2,000 \\
Ros. & M & W & 1,588 & 24 & 2,010 \\
Gaf. & M & W & 1,332 & 33 & 1,910 \\
& & & & &
\end{tabular}

* Day 0 is a hypothetical day when growth hormone would have been administered had these subjects been treated.

ories per $\mathrm{kg}$ of body weight per day by adjusting the amounts of formula every second day.

Human growth hormone was prepared by Dr. Maurice Raben from pituitary glands collected at autopsy and stored in acetone $(1,21)$. The powdered growth hormone was diluted in normal saline and the $\mathrm{pH}$ adjusted to 3.5 by addition of dilute hydrochloric acid. It was injected intramuscularly as a clear solution. No local or systemic reactions were encountered in any of the treated subjects.

Each infant was followed for a minimum of 3 weeks from the time he began to grow at a steady rate. The periods of study selected were the week before, the week during, and the week after growth hormone administration, each infant serving as his own control (Table I). In addition, a comparable group of 7 untreated infants was evaluated during the same time interval, and served as an additional control group (Table II).

The effects of growth hormone were studied by the following parameters.
A. Growth-promoting effects. Growth was estimated by: $a$ ) daily weight, $b$ ) head circumference measured in triplicate 6 days a week, and $c$ ) bi-weekly estimation of fibula length from X-ray films ${ }^{2}$ exposed at a constant target-film distance of 38 inches, according to the method of Day and Silverman (22). The fibula method for assessing linear growth was used because of its sensitivity and reproducibility and because of the inaccuracies inherent in measurements of body length in this age group. It reflects accurately general skeletal growth and can detect a significant increment in growth in infants in as short a period of time as 2.5 days (22). During exposure, care was taken to protect the gonads from radiation.

B. Metabolic effects. Determinations of the concentration of blood urea nitrogen $(23,24)$, blood sugar $(23$, $25)$, and serum phosphorus $(23,26)$ were obtained thrice weekly on venous blood collected according to a scalp vein technique previously described (27). The latter made it possible to obtain readily small serial samples of venous blood required' for selected chemical determinations.

In 2 infants of comparable weight and age, plasma free fatty acids (FFA) (28) were determined in the fasting

${ }^{2}$ Before obtaining roentgenograms of the fibula, the dose of radiation involved was carefully considered by the Pediatric X-ray Department. Dr. David H. Baker estimated the exposure to radiation as follows: "Radiographs were obtained using a Picker 500 ma machine equipped with a Picker double-diaphragm localizer. The gonads were shielded. The factors used were: $33 \mathrm{kv}$, $1 / 3$ second, $400 \mathrm{ma}$ at 38 inches. The calculated skin dose was 14 milliroentgens. The estimated fibula dose was less than 50 per cent of the skin dose. Radiation to the gonad and whole body was negligible. For comparison with the above, the average skin dose for a typical posterior-anterior chest film obtained with a standard X-ray machine is approximately 100 milliroentgens."

TABLE III

Weekly increments in weight, fibular length and head circumference during the study period

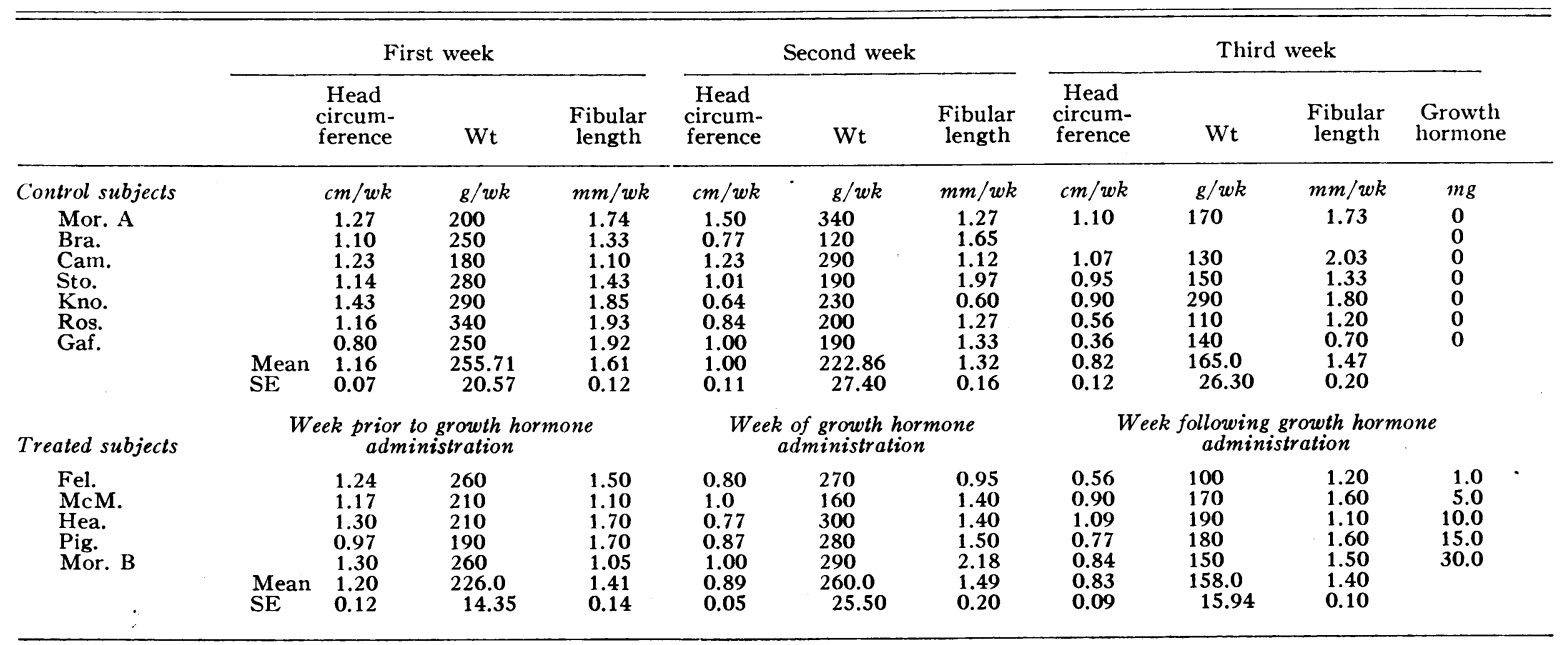



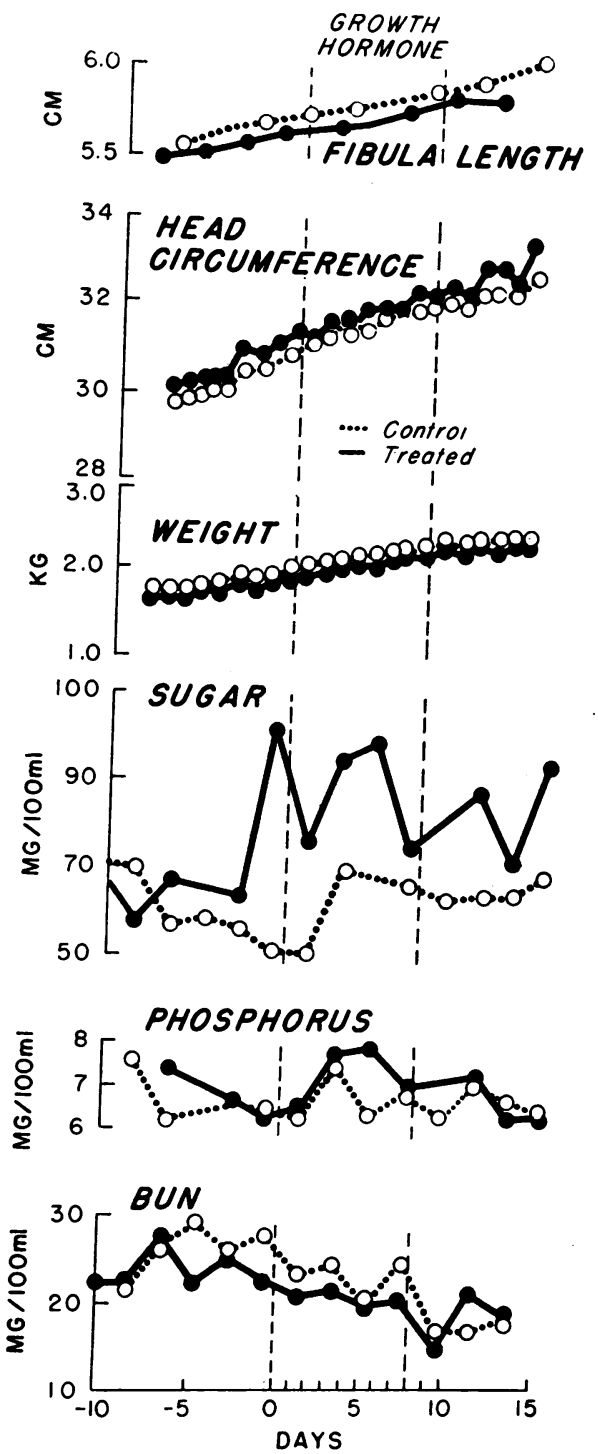

Fig. 1. A COMParison OF the MEAN VAlUes FOR VARIOUS PARAMETERS OF GROWTH HORMONE ACTIVITY IN PREMATURE INFANTS TREATED WITH HUMAN GROWTH HORMONE (DOTS AND SOLID LINES) AND IN CONTROL SUBJECTS (OPEN CIRCLES AND INTERRUPTED LINES). Human growth hormone was administered during the 8 day period between the vertical broken lines (see Table I for schedule of dosage).

state over a 4 hour period beginning at 8 a.m. In order to compare changes in the concentration of FFA elicited by fasting alone, and by fasting with the administration of growth hormone on the following day, $1.25 \mathrm{mg}$ of human growth hormone was injected intravenously over a 2 to 3 minute period after a 3 hour fast; the plasma FFA content was measured prior to injection and during the succeeding 4 hour period.

In addition, in 5 premature infants the concentration of "growth hormone" in serum was determined by the immunoassay method described by Read (29). Studies indicating a high degree of immunologic homogeneity of the Raben preparation of human growth hormone and of specificity of the rabbit anti-human growth hormone serum have been reported recently from our laboratory (30).

C. ACTH and growth hormone. One subject received sufficient ACTH to inhibit growth, at which time growth hormone was added in an attempt to evaluate its effect on the growth-suppressing action of ACTH. After a period of 4 days, both preparations were discontinued and the infant's response was observed (Table I).

\section{RESULTS}

Tables I and II compare the two groups of infants investigated. Table I shows the dosage and pattern of growth hormone administration in the treated subjects.

A. Growth-promoting effects. In Table III and Figure 1 are shown the mean values for measurements obtained in the control and treated groups of infants, expressed in weekly increments. Both groups were entirely comparable by all indices
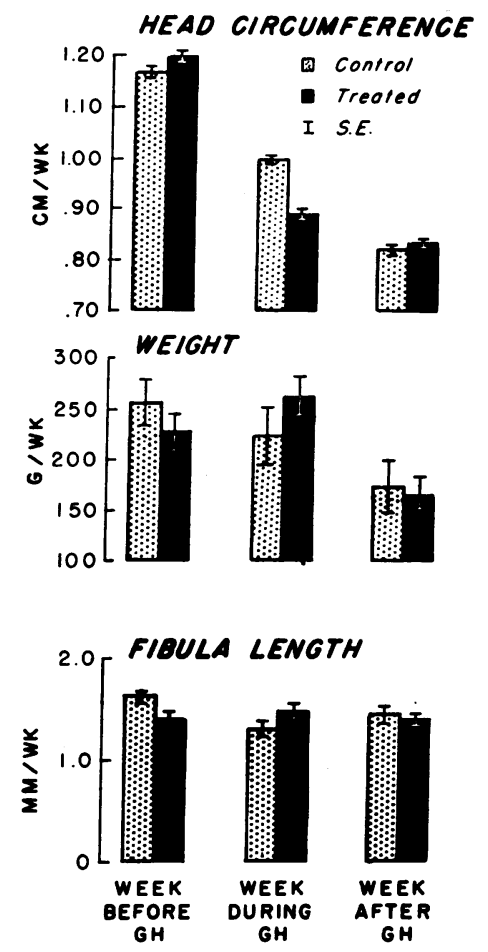

Fig. 2. The EFFECT OF hUMAN GROWTH HORMONE ON INDICES OF GROWTH IN THE PREMATURE INFANT. The stippled bars denote mean weekly increments for the control subjects and the solid bars for the treated subjects. The gradient represents \pm standard error of the mean. 

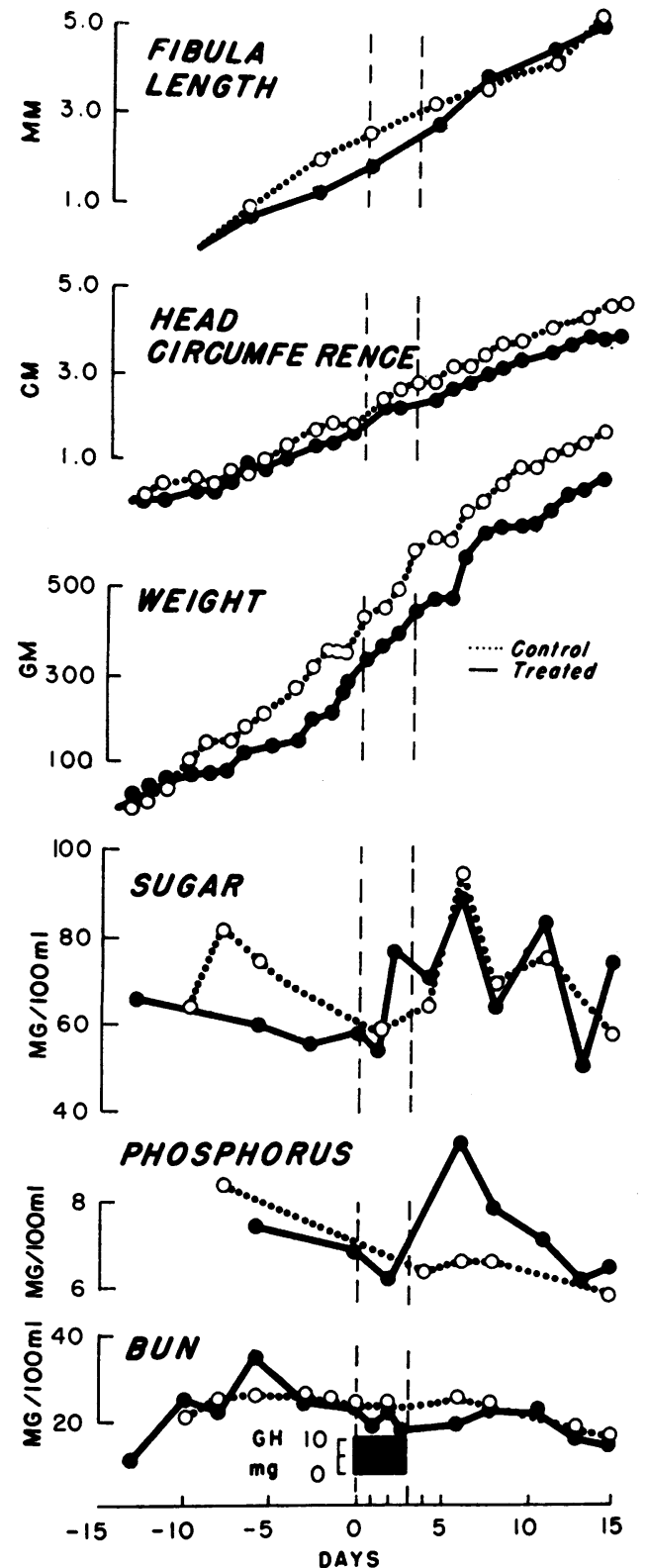

Fig. 3. The efFect OF HUMAN GROWTH HORMONE in MoR. B (DOTS AND SOLID LINES) IN CONTRAST to HiS Untreated identical twin, Mor. A (open circles and INTERRUPTED LINE). Measurements are expressed in cumulative increments.

studied (Figure 2). The mean differences between the two groups for head circumference, weight and increments in fibular length were not significant by Student's $t$ test (31).

Mor. A and Mor. B, identical twins (monozygosity suggested by the presence of a single placenta and identical blood group antigens), were also studied. The increment in fibular length for twin Mor. B who received the largest dose of growth hormone (10 $\mathrm{mg}$ a day for 3 days) was significantly greater $(p<0.001)$ than the mean value of the control group and the increment observed during the control period. This trend was not seen when twin Mor. B was compared to the control group for increments in weight and head circumference. Twin Mor. A on the other hand, showed no departure from the rest of the control group. In Figure 3 both twins are compared with respect to head circumference, weight and fibular length.

B. Metabolic effects. In the subjects who were given growth hormone a significant rise in blood sugar was observed $(0.05>p>0.02)$ from pretreatment values (Figure 1). In no instance was hypoglycemia encountered. In most infants studied, in both the control and treated groups, the level of blood urea nitrogen (BUN) was somewhat elevated, but the expected fall with advancing age was not significantly influenced by administration of growth hormone. Nevertheless, there was a tendency with the larger doses of growth hormone for the concentration of BUN to fall and of serum phosphorus to rise during the period of growth hormone administration (Figure 1) to a greater extent than in the control group of infants. This trend was also observed when Mor. A was compared with his monozygous twin Mor. B with respect to the concentration of BUN, blood sugar and serum phosphorus (Figure 3 ).

The results of determination of plasma FFA are shown in Table IV. The concentration of plasma FFA rose appreciably in the two infants studied, but no increase above the fasting values was observed following infusion with growth hormone.

The concentration of serum "growth hormone" in five premature infants varied between 230 and $480 \mathrm{~m} \mu \mathrm{g}$ per $\mathrm{ml}$, values within the range found in older infants and children by Read (29) and in our laboratory.

C. ACTH and growth hormone. In the subject who received $\mathrm{ACTH}$, growth inhibition was achieved, in agreement with previous studies (32, 33). The growth-suppressing action of ACTH was not altered by simultaneous administration of growth hormone, and the rebound which occurred following withdrawal of ACTH and growth hormone (Figure 4) was not greater than that ob- 
TABLE IV

The effect of fasting and of human growth hormone on the concentration of plasma free fatty acids

\begin{tabular}{|c|c|c|c|c|c|c|}
\hline \multicolumn{7}{|c|}{ Plasma free fatty acids $(\mu \mathrm{Eq} / \mathrm{L})$} \\
\hline \multirow{2}{*}{$\begin{array}{l}\text { Sub- } \\
\text { ject }\end{array}$} & \multicolumn{3}{|c|}{ Control (Day 1) } & \multicolumn{3}{|c|}{ Growth hormone (Day 2} \\
\hline & $0 \mathrm{hr} *$ & $2 \mathrm{hrs}$ & $4 \mathrm{hrs}$ & $0 \mathrm{hr} *$ & $2 \mathrm{hrs}$ & $4 \mathrm{hrs}$ \\
\hline 1 & 200 & 240 & 420 & 140 & 400 & 350 \\
\hline 2 & 110 & 370 & 820 & 370 & 650 & 750 \\
\hline
\end{tabular}

* 0 Hour corresponds to the time of growth hormone administration (1.25 mg i.v.) after a 2 to 3 hour fast. The subjects were tested on successive days.

served (32) in premature infants when ACTH was discontinued.

\section{DISCUSSION}

The data indicate that the immature human being is relatively unresponsive to the particular preparation as well as to the dosages of human growth hormone employed in these experiments. In contrast, this lot of Raben human growth hormone has been shown to exhibit highly potent biological activity when assayed in the hypophysectomized rat $(1,21)$ and to induce significant linear growth in hypopituitary dwarfs $(1,19,34,35)$, effects similar to those obtained with primate growth hormone prepared by $\mathrm{Li}$ [see Hutchings and co-workers (36) $]$. These, or comparable preparations of human growth hormone, have also shown significant biological activity in normal adult subjects and in persons with nonendocrine disorders $(1,19,37-39)$. In some of the latter studies $(37,38)$, the dose of hormone and the schedule of administration were similar to those used in the present experiments. Although biological changes, including a positive nitrogen balance, were clearly demonstrable in adult subjects, in three children (39), and in one 16 month old infant (40), the effect of growth hormone was more pronounced in hypopituitary dwarfs $(1,19)$. On the other hand, a relative lack of responsiveness (as calculated on the basis of body weight or of surface area) was exhibited by the premature infant to comparably large doses of human growth hormone. Only in Mor. B, the subject who received the largest dose of growth hormone, was a true growth-promoting effect obtained. It may be argued that balance studies would have provided a more sensitive in- dex of growth or of a protein anabolic response. However, serial measurements of the length of the fibula make possible the early and accurate detection of growth, and this method also assesses directly the stimulating effect of growth hormone on osteogenesis. In addition, the results obtained from the other parameters selected in the present study to. detect biological activity of exogenous growth hormone suggest that determinations of the output of nitrogen, phosphorus, and potassium in relation to their intake would not have provided a greater degree of sensitivity or precision.
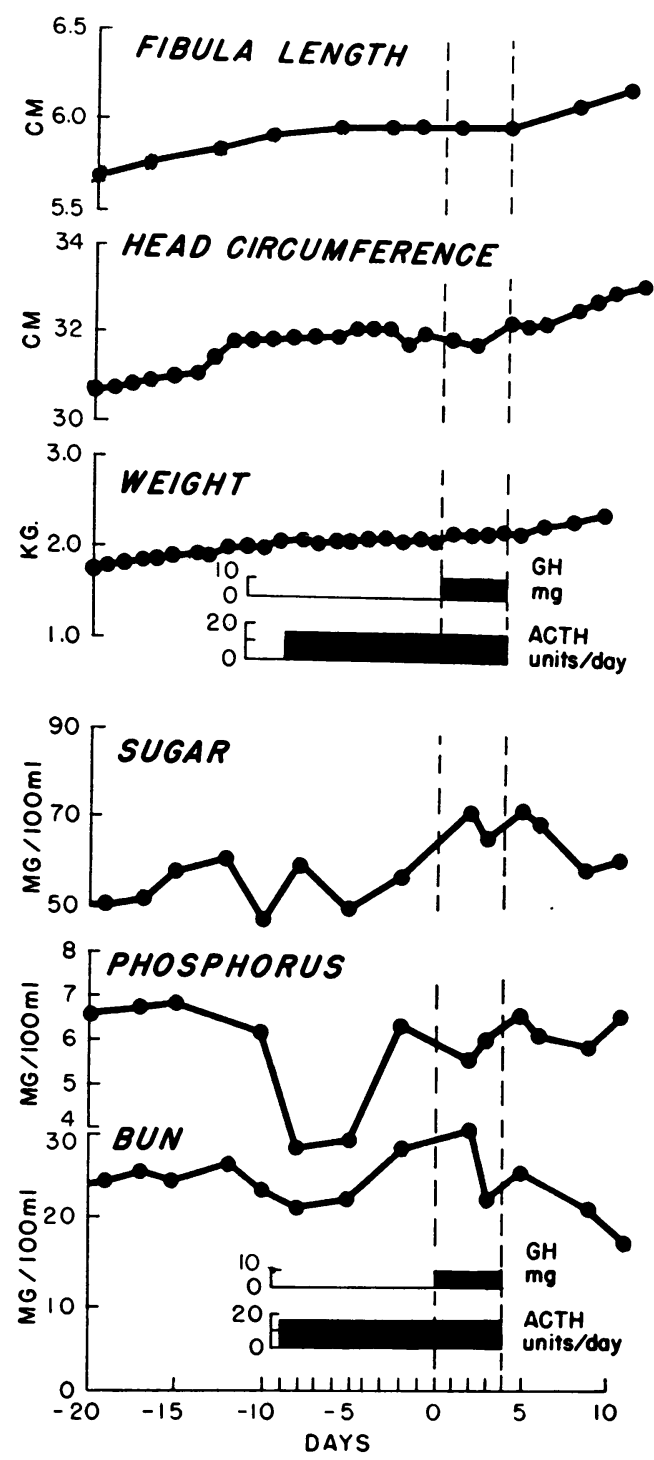

Fig. 4. THE EFFECT OF HUMAN GROWTH HORMONE ON THE GROWTH-SUPPRESSING ACTION OF ACTH IN A PREMATURE INFANT. 
When growth hormone is administered in an acid medium, its diabetogenic effect is diminished while its growth-promoting activity remains unaffected $(1,41)$. The Raben preparation is virtually nondiabetogenic in hypopituitary dwarfs, but Beck, McGarry, Dyrenfurth and Venning (19) noted decreased glucose tolerance in one subject who received large doses of hormone for 20 days. Young (42) has postulated that a capacity for linear growth seems to protect the young animal against the diabetogenic activity of growth hormone. The infants in this study responded to growth hormone with a significant rise in blood sugar content. It is noteworthy that the dose of growth hormone administered was large in relation to body weight and surface area.

Whereas hypophysectomy leads to a fall in serum phosphorus, growth hormone promotes phosphorus retention and an increased concentration of serum phosphorus and alkaline phosphatase (1, $13,43)$. In contrast to the preparation used in the British cooperative study (37), the Raben preparation of human growth hormone has uniformly produced a gradual rise in the concentration of serum phosphorus to prepubertal levels when administered to hypopituitary dwarfs and to normal adults $(1,19)$. In the treated group of premature infants a similar tendency was observed. Parenthetically, in the infant whose growth was temporarily arrested following administration of $\mathrm{ACTH}$, a sharp fall in the concentration of serum phosphorus occurred initially.

Recently Raben and Hollenberg (44) and Engel, Bergenstal, Nixon and Patten (45) have shown that human growth hormone, when administered to normal adult subjects and to hypopituitary dwarfs, causes a substantial increase in the concentration of plasma FFA, an effect attributed to the adipokinetic action of the hormone. The response of plasma fatty acids in the fasting state to small doses of growth hormone seems to be a highly sensitive and rapid method for detecting a growth hormone effect (1). It is of interest that exogenous growth hormone dicl not induce such a response in the two premature infants studied, although the concentration of plasma fatty acids rose with fasting. These findings provide additional evidence of the relative unresponsiveness of the immature human subject to administered growth hormone.
The role of growth hormone in the fetus and neonate is poorly understood. The resistance of the immature human being to exogenous growth hormone could be attributable to the fact that growth hormone at this stage of the life cycle does not play an essential part in embryonic, fetal, and early postnatal growth, or that its action on this process is primarily a permissive one. On the other hand, it is also possible that the fetus and neonate are already stimulated maximally by endogenous sources of growth hormone.

Hypophysectomy of either the mother or fetus has been reported to have no effect, or only a slight one, upon fetal growth in the chick, mouse, rat or rabbit (12, 46-50). Smith (51) has shown that the offspring of monkeys hypophysectomized during pregnancy were of normal sitting height at birth and had a birth weight within the normal range, although lower than that of control animals. Lack of a fetal hypophysis, occurring spontaneously or following experimental ablation, in the chick, mouse, rat $^{3}$ and rabbit either had no effect on body growth or was associated with near normal growth (12, 46-49). Jost and Picon (47) concluded from the results of their experiments and those of other experimental embryologists: "So far, . . . no hormone is known which is essential to the foetus for the performance of its share in achieving its own growth."

In placental mammals direct evidence is lacking that growth hormone is transferred across the placenta. Yet, in man as well as in the chick, mouse, rat and rabbit, absence of the fetal hypophysis does not seem to influence, to any degree, embryonic and fetal growth. Apituitary and acephalic human fetuses in general have not shown appreciable deviations from the norm in length or weight at birth when these measurements are corrected for the cerebral defect $(15-18,52)$. An

3 Wells (49), with Heggestad, found that rat fetuses decapitated 50 hours before term weighed less than litter mates decapitated at delivery. In contrast to other workers, they interpreted their experiments as indicating that growth hormone may affect the weight of the fetus. However, it is questionable whether the unoperated litter mates may be considered a proper control animal. In view of the effects of operative manipulation on fetal animals we have chosen to give most weight to those experiments in which a negligible influence of fetal hypophysectomy on growth was demonstrated. 
infant born of a mother hypophysectomized during the twenty-fifth week of pregnancy for carcinoma of the breast was of normal size when delivered at 35 weeks (53). Similarly, infants born of mothers with active acromegaly have not been excessively large (10-12).

The normal birth weight and growth during infancy of idiopathic hypopituitary dwarfs seem to support further the limited influence of growth hormone as a growth-promoting agent during gestation and infancy $(14,54)$. It has been shown that rats hypophysectomized as early as 6 days of age continue to grow at approximately half the rate of the unoperated control group until about 30 days after birth, after which time growth stops $(55,56)$. In contrast, cessation of body growth occurs rather abruptly following the removal of the rat's hypophysis at 28 days. Mice affected with hereditary anterior pituitary dwarfism exhibit a steady rate of growth for the first week or so of life, although degenerative changes in the eosinophilic cells of the anterior hypophysis are detectable microscopically before birth (57). These observations would seem to indicate an appreciable capacity for growth of placental mammals in early life independent of the anterior hypophysis.

The detection of growth hormone in the plasma of the premature infant indicates that at this age the anterior hypophysis is capable of synthesizing and secreting sufficient growth hormone to maintain a concentration in the circulation at least equal to that found in children. Indeed, Smith and Dortzbach (58) have demonstrated that early in fetal life the hypophysis of the fetal pig has a specific growth-promoting effect when implanted into the hypophysectomized rat, and the activity once detected increased with advancing fetal age. Gershberg (59) has shown that the concentration of growth hormone in human pituitary glands, as determined by bioassay, varies little with age.

It is common knowledge that growth hormone has a general anabolic action and effects an increase in the mass of most body tissues. A considerable body of data, recently reviewed $(1,14$, 60-62), provides substantial evidence of the influence of growth hormone on carbohydrate, fat, protein and mineral metabolism. Nonetheless, the primary action of growth hormone is still obscure. Recently, there has been renewed interest in the effect of growth hormone on the mobilization and oxidation of fat and the relationship of this effect to its anabolic action. Greenbaum $(63,64)$ has shown, from carcass analyses of normal and growth hormone-treated rats on a restricted diet, that protein synthesis ceases when available fat reserves for catabolism have been exhausted. Evidence adduced from an accumulating body of data (1) suggests, but has not established, that an intrinsic effect of growth hormone is to promote the catabolism and utilization of fat which, in the presence of an adequate supply of dietary amino acids, leads to protein deposition and diminished protein oxidation. It is of interest that obesity is exceedingly rare in acromegaly.

In the light of the action of growth hormone on adipose tissue it is noteworthy that the premature infant has little subcutaneous fat. Fehling in 1877 (65) and Wilmer in $1940(66,67)$ demonstrated that the fat content of the fetus increases rapidly during the third trimester of gestation. In a comprehensive study of body composition by Widdowson and Spray (68), most of the increase in fat stores was found to occur between the end of the eighth month and term. Carcass analysis of a $1,500 \mathrm{~g}$ premature infant showed only 3.5 per cent fat as compared with analyses of a 2,500 and a $3,500 \mathrm{~g}$ infant which yielded 7.6 per cent and 16.2 per cent fat, respectively. It is necessary to consider the possibility that the meager labile fat stores characteristic of the premature infant may play a role in the relative unresponsiveness of the premature infant to the administration of growth hormone.

On the other hand, the premature infant on a diet providing adequate calories and protein often grows at a near maximal rate which may, at least in part, be independent of endogenous growth hormone. Furthermore, the premature infant when fasted shows a rise in the concentration of plasma FFA which indicates an ability to mobilize fat. Hence, it is curious that no additional increase in the concentration of FFA was obtained following the injection of a large close of growth hormone. In addition, growth hormone failed to counteract the growth-suppressing action of ACTH in the subject who received both hormones concurrently. This finding contrasts with the observation of Selye in the rat (69) and the positive nitrogen balance ohtained with human growth 
hormone in an adult with Cushing's syndrome (39).

The data obtained in this study indicate that the premature infant is relatively unresponsive to the growth-promoting and metabolic effects of exogenous growth hormone. It does not, however, establish whether growth in the newborn and neonatal period is dependent on growth hormone as it is at later ages or whether, as appears to be the case in the fetus, it is essentially independent of circulating growth hormone and related to an intrinsic capacity for growth. It would seem from the available information that the young infant is in a transitional state, in which growth hormone assumes a progressively more significant function as a regulator of body growth. Although in the present study the period of growth hormone administration was short, the limited effect in our subjects provides additional evidence (70) against the notion that the macrosomia observed in infants born to prediabetic and diabetic mothers is induced by maternal growth hormone transferred across the placenta.

\section{SUMMARY}

Human growth hormone was administered intramuscularly to six premature infants and the effects assessed by comparison with the pre- and posttreatment periods and with a control group of seven subjects.

1. A definite increase in the concentration of blood sugar was elicited; the concentration of serum inorganic phosphorus tended to increase and the concentration of blood urea nitrogen to decrease.

2. A significant increment in head circumference and weight was not obtained, nor was an increase in the rate of growth of the fibula detected, except in one subject who received the largest amount of growth hormone (10 $\mathrm{mg}$ per day for three days).

3. Growth hormone injected intravenously failed to augment the increased concentration of plasma free fatty acids obtained by fasting alone.

4. Suppression of growth induced with ACTH was not affected by the concurrent administration of growth hormone.

5. Growth hormone was detected in the plasma of the premature infant.
It is concluded that the premature infant is relatively unresponsive to the action of exogenous growth hormone. This contention is examined in the light of results of experiments in placental mammals and the findings in fetal and postnatal hypopituitarism in man.

\section{ACKNOWLEDGMENT}

We wish to thank Dr. Maurice Raben for preparing the human growth hormone and for his many kindnesses. The authors gratefully acknowledge Dr. William A. Silverman, Director of the Premature Unit, and Miss Priscilla Parke and the nurses of the Premature Unit, Babies Hospital, for their splendid cooperation. Dr. Melvin S. Schwartz provided advice and assistance in the statistical analysis of the data. Mr. Lester Baker contributed to the initial part of this study.

\section{REFERENCES}

1. Raben, M. S. Human growth hormone. Recent Progr. Hormone Res. 1959, 15, 71.

2. Barns, H. H. F., Lindan, O., Morgans, M. E., Reid, E., and Swyer, G. I. M. Foetal mortality in pregnant rats treated with anterior-pituitary extracts and in alloxan-diabetic rats. Lancet 1950, 2, 841.

3. Cotes, P. M. The weights of litters produced by female rats treated with anterior pituitary growth hormone during pregnancy. J. Endocr. 1954, 10, xiv.

4. Engfeldt, B., and Hultquist, G. T. Administration of crystalline growth hormone to pregnant rats. Acta endocr. (Kbh.) 1953, 14, 181.

5. Hultquist, G. T., and Engfeldt, B. Giant growth of rat fetuses produced experimentally by means of administration of hormones to the mother during pregnancy. Acta endocr. (Kbh.) 1949, 3, 365.

6. Abaza, A., Varroud-Vial, J., and Rombauts, M. Syndome de Young (croissance prolongée, mortalité foetale ou néonatale élevée, gros enfants, hyperlactation, obésité, diabète). Presse méd. 1953, $61,495$.

7. Barns, H. H. F., and Morgans, M. E. Prediabetic pregnancy. J. Obstet. Gynaec. Brit. Emp. 1948, 55, 449.

8. Barns, H. H. F., and Morgans, M. E. Pregnancy complicated by diabetes mellitus. Brit. med. J. 1949, 1, 51.

9. Gilbert, J. A. L. The association of maternal obesity, large babies, and diabetes. Brit. med. J. 1949, 1, 702.

10. Abelove, W. A., Rupp, J. J., and Paschkis, K. E. Acromegaly and pregnancy. J. clin. Endocr. 1954, $14,32$.

11. Jackson, W. P. U. The prediabetic syndrome. Large babies and the (pre)diabetic father. J. clin. Endocr. 1954, 14, 177. 
12. Tuchmann-Duplessis, H. Hormones Hypophysaires Somatotrope et Corticotropc, Croissance et Métabolisme. Paris, Masson et Cie, 1956.

13. Jost, A. Hormonal factors in the development of the fetus. Cold Spr. Harb. Symp. quant. Biol. 1954, 19, 167.

14. Astwood, E. B. Growth hormone and corticotropin in The Hormones, G. Pincus and K. V. Thimann, Eds. New York, Academic Press, 1955, vol. 3, p. 235.

15. Pennell, M. T., and Kukral, A. J. An unusual case of holoacephalus. Amer. J. Obstet. Gynec. 1946, 52, 669.

16. Blizzard, R. M., and Alberts, M. Hypopituitarism, hypoadrenalism, and hypogonadism in the newborn infant. J. Pediat. 1956, 48, 782.

17. Brewer, D. B. Congenital absence of the pituitary gland and its consequences. J. Path. Bact. 1957, 73, 59.

18. Blanc, W. A., and Grumbach, M. M. Unpublished data. (Babies Hospital Autopsy no. 8577.)

19. Beck, J. C., McGarry, E. E., Dyrenfurth, I., and Venning, E. H. The metabolic effects of human and monkey growth hormone in man. Ann. intern. Med. 1958, 49, 1090.

20. Knobil, E., and Greep, R. O. The physiology of growth hormone with particular reference to its action in the rhesus monkey and the "species specificity" problem. Recent Progr. Hormone Res. 1959, 15, 1.

21. Raben, M. S. Preparation of growth hormone from pituitaries of man and monkey. Science 1957, 125, 883.

22. Day, R., and Silverman, W. A. Growth of the fibula of premature infants as estimated in roentgen films: A method for assessing factors promoting or inhibiting growth. Et. néo-natal. 1952, $1,111$.

23. Skeggs, L. T., Jr. An automatic method for colorimetric analysis. Amer. J. clin. Path. 1957, 28, 311.

24. Marsh, W. H., Fingerhut, B., and Kirsch, E. Determination of urea nitrogen with the diacetyl method and an automatic dialyzing apparatus. Amer. J. clin. Path. 1957, 28, 681.

25. Hoffman, W. S. A rapid photoelectric method for the determination of glucose in blood and urine. J. biol. Chem. 1937, 120, 51.

26. Benedict, S. R., and Theis, R. C. A modification of the molybdic method for the determination of inorganic phosphorus in serum. J. biol. Chem. 1924, $61,63$.

27. Ducharme, J. R., and Grumbach, M. M. A modification of the López Banús method for collecting samples of venous blood from young infants. Pediatrics 1959, 23, 756.

28. Gordon, R. S., Jr. Unesterified fatty acid in human blood plasma. II. The transport function of unesterified fatty acid. J. clin. Invest. 1957, 36, 810.
29. Read, C. H. The immunologic assay of human growth hormone in Clinical Endocrinology, I, E. B. Astwood, Ed. New York, Grune \& Stratton, 1960 , p. 598.

30. Grumbach, M. M., Kaplan, S. L., and Solomon, S. Immunochemical observations on antisera to purified human growth hormone. Nature (Lond.) 1960, 185, 170.

31. Snedecor, G. W. Statistical Methods Applied to Experiments in Agriculture and Biology, 5th ed. Ames, Iowa, State College Press, 1956.

32. Silverman, W. A., Day, R. L., and Blodi, F. C. Inhibition of growth and other effects of ACTH in premature infants. Pediatrics 1951, 8, 177.

33. Becks, H., Simpson, M. E., Li, C. H., and Evans, H. M. Effects of adrenocorticotropic hormone $(\mathrm{ACTH})$ on the osseous system in normal rats. Endocrinology 1944, 34, 305.

34. Raben, M. S. Treatment of a pituitary dwarf with human growth hormone. J. clin. Endocr. 1958, 18, 901.

35. Henneman, P. H., Moldawer, M., Carroll, E. L., Mitchell, M., and Waddell, M. J. Human growth hormone; prolonged administration of moderate doses in three patients with panhypopituitarism (abstract 40). J. clin. Endocr. 1958, 18, 548.

36. Hutchings, J. J., Escamilla, R. F., Deamer, W. C., and $\mathrm{Li}, \mathrm{C}$. $\mathrm{H}$. Metabolic changes produced by human growth hormone $(\mathrm{Li})$ in a pituitary dwarf. J. clin. Endocr. 1959, 19, 759.

37. Panel appointed by the Clinical Endocrinology Committee of the Medical Research Council. The effectiveness in man of human growth hormone. Lancet 1959, $1,7$.

38. Ikkos, D., Luft, R., and Gemzell, C. A. The effect of human growth hormone in man. Lancet 1958, $1,720$.

39. Lipsett, M. B. Personal communication.

40. Crigler, J. F., Jr., Knapp, J. A., and Chagnon, J. Observations on the metabolic effects of glucagon and growth hormone (human and beef) in an infant with idiopathic hypoglycemia and hyperinsulinism (abstract 5). Program of the TwentyEighth Annual Meeting Soc. Pediatr. Res. Atlantic City, N. J., 1958.

41. Lazo-Wasem, E. A., and Graham, C. E. Comparative potency of growth hormone preparations in alkali or acid. Endocrinology 1958, 62, 108.

42. Young, F. G. Growth hormone and diabetes. Recent Progr. Hormone Res. 1953, 8, 471.

43. Li, C. H., Simpson, M. E., and Evans, H. M. The growth of hypophysectomized female rats following chronic treatment with pure pituitary growth hormone. II. Some chemical components of the musculature, liver and blood plasma. Growth 1949, 13, 171.

44. Raben, M. S., and Hollenberg, C. H. Effect of growth hormone on plasma fatty acids. J. clin. Invest. 1959, 38, 484. 
45. Engel, H. R., Bergenstal, D. M., Nixon, W. E., and Patten, J. A. Effect of human growth hormone on UFA and plasma amino acid nitrogen in man. Proc. Soc. exp. Biol. (N. Y.) 1959, 100, 699.

46. Stoll, R. L' agénésie de l'hypophyse et de la thyroïde est sans influence sur le développement de l'embryon de poulet. C.R. Soc. Biol. (Paris) 1939, 130, 926.

47. Jost, A., and Picon, L. Hormonal factors in the growth of the foetus in The Biological Actions of Growth Substances. Symp. Soc. exp. Biol. 1957, 11, 228.

48. Raynaud, A. Effects of destruction of the fetal hypophysis by $\mathrm{x}$-rays upon sexual development of the mouse in Symposium on Comparative Endocrinology, A. Gorbman, Ed. New York, John Wiley \& Sons, 1959, p. 452.

49. Wells, L. J. Effect of fetal endocrines on fetal growth in Gestation, Transactions of Third Conference, C. A. Villee, Ed. New York, Josiah Macy, Jr. Foundation 1957, p. 187.

50. Knobil, E., and Caton, W. L. The effect of hypophysectomy on fetal and placental growth in the rat. Endocrinology 1953, 53, 198.

51. Smith, P. E. Continuation of pregnancy in rhesus monkeys (Macaca mulatta) following hypophysectomy. Endocrinology 1954, 55, 655.

52. André-Thomas, Lepage, F., and Sorrel-Dejerine. Examen anatomo-clinique de deux anencéphales protubérantiels. Rev. neurol. 1944, 76, 173.

53. Little, B., Smith, O. W., Jessiman, A. G., Selenkow, H. A., Van't Hoff, W., Eglin, J. M., and Moore, F. D. Hypophysectomy during pregnancy in a patient with cancer of the breast: Case report with hormone studies. J. clin. Endocr. 1958, 18, 425.

54. Martin, M. M., and Wilkins, L. Pituitary dwarfism: Diagnosis and treatment. J. clin. Endocr. 1958, 18, 679.

55. Simpson, M. E., Asling, C. W., and Evans, H. M. Some endocrine influences on skeletal growth and differentiation. Yale J. Biol. Med. 1950, 23, 1.

56. Walker, D. G., Asling, C. W., Simpson, M. E., Li, C. H., and Evans, H. M. Structural alterations in rats hypophysectomized at six days of age and their correction with growth hormone. Anat. Rec. 1952, 114, 19.

57. Francis, T. Investigations into the Development of the Pituitary at Hereditary Anterior Pituitary Dwarfism in Mice, with Reference to the Patho- genesis of the Anterior Pituitary Dwarfism. Copenhagen, Ejnar Munksgaard, 1944.

58. Simith, P. E., and Dortzbach, C. The first appearance in the anterior pituitary of the developing pig foetus of detectable amounts of the hormones stimulating ovarian maturity and general body growth. Anat. Rec. 1929, 43, 277.

59. Gershberg, H. Growth hormone content and metabolic actions of human pituitary glands. Endocrinology 1957, 61, 160.

60. Russell, J. A. Effects of growth hormone on protein and carbohydrate metabolism. Amer. J. clin. Nutr. 1957, 5, 404.

61. de Bodo, R. C., and Altszuler, N. The metabolic effects of growth hormone and their physiological significance in Vitamins and Hormones, R. S. Harris, G. F. Marrian and K. V. Thimann, Eds. New York, Academic Press, 1957, vol. 15, p. 205.

62. Ketterer, B., Randle, P. J., and Young, F. G. The pituitary growth hormone and metabolic processes. Ergebn. Physiol. 1957, 49, 127.

63. Greenbaum, A. L. Changes in body composition and respiratory quotient of adult female rats treated with purified growth hormone. Biochem. J. 1953, 54, 400.

64. Greenbaum, A. L. Growth hormone and fat metabolism in The Hypophyseal Growth Hormone, Nature and Actions, R. W. Smith, Jr., O. H. Gaebler and C. N. H. Long, Eds. New York, McGrawHill, 1955, p. 330.

65. Fehling, H. Beiträge zur Physiologie des placentaren Stoff verkehrs. Arch. Gynäk. 1877, 11, 523.

66. Wilmer, H. A. Quantitative growth of skin and subcutaneous tissue in relation to human surface area. Proc. Soc. exp. Biol. (N. Y.) 1940, 43, 386.

67. Wilmer, H. A. Changes in structural components of human body from six lunar months to maturity. Proc. Soc. exp. Biol. (N. Y.) 1940, 43, 545.

68. Widdowson, E. M., and Spray, C. M. Chemical development in utero. Arch Dis. Childh. 1951, 26, 205.

69. Selye, H. Prevention by somatotrophin of the catabolism which normally occurs during stress. Endocrinology 1951, 49, 197.

70. Mercier-Parot, L., and Tuchmann-Duplessis, $H$. L'hormone somatotrope provoque-t-elle du gigantisme foetal? C.R. Acad. Sci. (Paris) 1955, 240, 455 . 